\title{
Emancipation from Work or Emancipation through Work? \\ Aesthetics of Work and Idleness in Recent French Thought
}

In his Le Capitalisme cognitif (2007), Yann Moulier Boutang argues that we have now entered a new mode of capitalist accumulation, in which surplus value is no longer primarily derived by exploiting the physical labour of the Fordist assembly-line worker. Rather, in this Post-Fordist conjuncture the extraction of surplus value demands the exploitation and implication of contemporary workers' cognitive, affective, and cooperative capacities in their productive activities. Under Fordism, assembly-line workers were compelled to perform a series of mindless, repetitive tasks, tasks that were 'parcellised' in accordance with the precepts of Taylorist 'scientific management' and hence demanded little in the way of initiative, creativity, cooperation, or even communication between co-workers. Under Post-Fordism, by contrast, those creative, cooperative, and communicative capacities come to the fore, whether in an expanded tertiary sector or in a modernised manufacturing sector, characterised by techniques of Just-in-Time production and Total Quality Management that require workers to invest ever greater levels of personal initiative in their tasks. As a result, Moulier Boutang suggests, 'le capitalisme cognitif cherche désormais ses modèles du côté de l'art et de I'Université'. ${ }^{1}$ In 'cognitive capitalism', then, work will engage the worker's affects and intellect to such a degree as to become analogous to artistic or intellectual production, a form of productive activity that, like the aesthetic object, finds an end in itself.

In drawing this analogy between 'cognitive capitalism' and the realm of art, Moulier Boutang is echoing Paolo Virno's claim, in his Grammar of the Multitude (2004), that under Post-Fordism 'virtuosity' or 'virtuosic performance' have become the keys to the extraction of surplus value. ${ }^{2}$ Virno returns to Marx's definition in Capital of a subcategory of waged labour that produces no separable end product, the kind of labour engaged in by pianists, butlers, dancers, teachers, priests, and medical doctors. This 
kind of labour, which depends on the presence of others and finds its own fulfilment in itself, demands, Virno (GoM, p.61) argues, the sort of 'virtuosic performance' that has now become characteristic of the affective, cognitive labour that is key to Post-Fordist accumulation: 'in the post-Ford era, activity without an end product, previously a special and problematic case, $[\ldots]$ becomes the prototype of all waged labour'. Inasmuch as such 'virtuosity' remains subservient to the wage relation, Virno (GoM, p.68) maintains that 'virtuosic activity shows itself as universal servile work'. Yet, Moulier Boutang insists that however effective capitalism appears to be in extracting surplus value from the cognitive, communicative, and affective capacities of its wage slaves, there remains something within those capacities that may yet prove irreducible to capitalist exploitation, something that constitutes 'un défi sans précédent pour l'entreprise, le marché et l'Etat, ainsi que pour les formes de la démocratie représentative' (Cc, p.166). Thus both Virno's and Moulier Boutang's accounts of the 'virtuosic' character of work under 'cognitive capitalism' are haunted by the possibility that, in seeking to integrate such irreducibly human capacities into its regime of accumulation, capitalism may yet prove to be its own gravedigger, unwittingly hastening the advent of some new Aesthetic State in which work will truly be modelled on the aesthetic, finding its own end in itself.

\section{Neo-operaism's Aesthetics of Work}

Moulier Boutang and Virno both belong to that broad current in Marxism known as 'neooperaism', whose best-known text is Michael Hardt and Toni Negri's Empire (2000) and whose most influential manifestation in the French context is the journal Multitudes, of which Moulier Boutang is General Editor. As its name suggests, neo-operaism is a more recent iteration of the Italian 'operaïste' or 'workerist' current of the 1960 s and 70s. A founding assumption of operaism is what Mario Tronti famously termed 'the inversion of perspective', whereby the primary motor of history is taken to be not the development of capitalism according to its own autonomous logic but rather the productive force of the working class itself. Thus, for example, operaists understand Fordism to be less the 
product of technological and economic developments per se than the response of capital to the continuing autonomy of independent artisanal or semi-artisanal forms of labour. By drafting and disciplining massed workers into the Fordist factory, by rigidly separating command from execution and breaking productive tasks down into a series of mindless, unthinking, and non-communicative actions, capital was thus able to capture and control the workers' inherent productive force, rendering that force amenable to economic exploitation. In so doing, however, capitalism was forced to integrate into itself a force antagonistic to its own interests. That antagonism manifested itself in the phenomenon of workers' refusal, in the strikes, slow-downs, or acts of sabotage by which the workers demonstrated that it was in fact they who were the true motor force behind capital accumulation and economic development. ${ }^{3}$

Neo-operaists would, by extension, understand the strikes and protests of May 1968 as a mass refusal of the discipline of Fordism, in the name of greater freedom, autonomy and initiative in the workplace and across society as a whole. Post-Fordist modes of production would then be understood as capitalism's enforced response to the movements of 1968 and after, in the form of attempts to integrate that desire for greater autonomy into the process of capitalist accumulation itself, in a new 'apparatus of capture' that rendered workers' autonomous productive power controllable and exploitable once more. Typically, neo-operaists read this shift from Fordist to PostFordist modes of production in terms of the shift between Foucault's 'disciplinary society' and what Gilles Deleuze termed an emergent 'society of control', characterised by less overtly coercive, more 'modulated' but nonetheless exploitative apparatuses of power. ${ }^{4}$ Despite this engagement with Foucault and Deleuze, neo-operaists continue to adhere to a fundamentally dialectical conception of history, positing the affective and cognitive capacities now integrated into 'cognitive capitalism' as a force of negativity that contains the seeds of some future emancipation, in ways that our discussion of Moulier Boutang and Virno should have made clear. 
It is this continuing adherence to a dialectical conception of history that Jacques Rancière has criticised. In a comment on Hardt and Negri's Empire that is equally applicable to Moulier Boutang's work, he casts doubt on this assumption that the new mode of production 'serait voué à exploser sous l'effet même des nouvelles forces productives qu'il développe et qui portent en elles-mêmes un nouveau monde social'. He continues: 'Cette thèse n'a jamais été confirmée par le développement du capitalisme, qui a toujours avalé les technologies qui devaient le faire exploser'. In the face of this historical failure of the Marxist dialectic to work itself out in the way its adherents predict, Rancière suggests that genuine emancipation must be sought elsewhere, 'ailleurs que dans I'organisation capitaliste des forces de production: dans la multiplicité anonyme des affirmations de la capacité de n'importe qui'. ${ }^{5}$ By an apparent paradox, Rancière finds in the aesthetic a model for this other form of emancipation, for this scene where everyone and anyone can manifest an equal capacity. However, in stark contrast to Moulier Boutang, he understands the aesthetic as corresponding to a moment of 'idleness', in which any logic of productive labour is 'suspended', allowing workers to glimpse an identity and a destiny for themselves different to that defined by their place in the relations of production.

As we have noted, Moulier Boutang appears to hold out the promise of emancipation through a kind of 'aesthetics of work', in which the new cognitive worker will achieve freedom by re-appropriating her alienated cognitive and affective capacities, such that work may find an end in itself and hence become analogous to aesthetic experience. From Rancière's point of view, this would amount to merely the latest iteration of an 'ethical' conception of aesthetics that threatens to suppress the 'dissensual' nature of the aesthetic in favour of a new consensual community of feeling. Thus, to Moulier Boutang's 'aesthetics of work', Rancière will oppose what we might term an 'aesthetics of idleness', in which the aesthetic is taken to figure not some future harmonious community but an egalitarian moment that disrupts or suspends any such community. In what follows, this article will examine Rancière's 'aesthetic of idleness' in more detail, clarifying its 
distinction from any 'ethical' conception of art or aesthetics. It will then consider the most frequent criticism that Rancière's work has attracted, namely that his focus on such fleeting moments of disruption or suspense is unrealistic or idealistic, a 'fantasy', to quote one recent critic, $^{6}$ that wilfully ignores the material determinants of lasting political action. This, finally, will involve turning to the most recent work of Maurizio Lazzarato. Formerly a collaborator of Moulier Boutang's and a member of the editorial board of Multitudes, over the last few years Lazzarato has distanced himself from the neooperaist focus on diagnosing the economic forms and political possibilities of 'cognitive capitalism'. For Lazzarato, the defining characteristic of the contemporary economic conjuncture is less the exploitation of workers' affective and cognitive capacities than the use of debt as a generalized mechanism of social control and economic exploitation. As a corollary to this, he has been forced to seek alternative paths to emancipation than that supposedly offered by the promise of a collective re-appropriation of those cognitive and affective capacities. This, in turn, has led him to place a renewed emphasis on the refusal of work as a primary political tactic, yet this is a notion of refusal that bears the traces of a significant engagement with Rancière's thought. In this sense, Lazzarato seems to have joined Rancière in suggesting that any political emancipation will have to take the form of an emancipation from work, rather than an emancipation through work. $^{7}$

\section{$\underline{\text { Rancière's Aesthetics of Idleness }}$}

Rancière's rejection of any dream of emancipation through the collective reappropriation of workers' productive capacities is not purely theoretical, it is also rooted in his archival studies of the nineteenth-century French workers movement. In La Nuit des prolétaires (1981), he offers numerous of examples of workers who, in fact, rejected any dream of re-appropriating the efforts and products of their labours, any dream of emancipation through labour. The texts authored by the worker-poets and philosophers he studies show a keen understanding that to re-appropriate the products of one's 
labours by having a greater personal investment in and rational understanding of the production process offers no form of emancipation at all. Rather, what this promises is an even more profound form of servitude in that not only the workers' physical force but also their intellectual and affective capacities will now be exploited and expropriated. To quote Rancière: 'la qualification de la tâche qui fait que l'esprit est occupé avec le corps, ne saurait faire compensation à la douleur du travail pour vivre. Elle la renforce au contraire quand elle fait mordre le temps de la servitude nécessaire sur le temps de la liberté possible'. ${ }^{8}$

In rejecting this long-standing dream of 'la belle harmonie d'une intelligence attentive servie par une main habile' (Nuit, p.71), Rancière's worker-intellectuals rub up against various forms of utopian socialism, displacing, by their words and actions, those doctrines' belief that emancipation would come from some form of rationalisation or reappropriation of the processes and products of labour. In seeking emancipation elsewhere, through a 'suspension' of the logic of work, these proletarian philosophers staged a 'rupture' with their presumed identities and destinies as workers, laying claim to a fundamental equality and right to freedom contingent on their status as human beings. Rancière finds a theoretical model for these moments of emancipation through 'rupture', 'dissensus', and 'suspension' of the logic of labour in the founding texts of modern aesthetics. He thus offers an interpretation of the political potential of the aesthetic that seems directly opposed to what we have termed Moulier Boutang's 'aesthetics of work'. Exemplary here would be the case of the carpenter Gabriel Gauny, who recounts momentarily stepping back from his labours installing the parquet floor of a bourgeois residence to engage in a moment of leisurely, idle, disinterested aesthetic contemplation of the view from the window of the room in which he was working (Nuit, p.91). Acting for a moment as if the house belonged to him and not his bourgeois master, as if it were the site not of exploitation but of aesthetic appreciation, Gauny unwittingly realised Kant's prescriptions for leisurely aesthetic contemplation, for the appreciation of the Beautiful. 
For Kant, aesthetic appreciation demands a 'leisurely', 'disinterested' gaze that attends purely to the form of the aesthetic object, ignoring any consideration of its function. It is because of its disinterestedness that aesthetic appreciation can lay claim to the universality of its judgements of taste, to their universal communicability. In the absence of such disinterest, judgements of taste remain narrowly particular, reflecting an individual's purely personal appetites or partial interests. In suspending his labours to appreciate the view from the window on disinterested aesthetic terms, Gauny experiences a moment of equality and a promise of emancipation - equality through appreciating the universal communicability of a Beauty available to everyone, regardless of their social status; emancipation by staging a rupture with the dominant distribution of social roles and places, what Rancière terms 'le partage du sensible', to lay claim to a capacity to feel, do, and be something else than what his identity as 'worker' prescribes for him.

If Rancière finds in Kant's Third Critique the first philosophical elaboration of the emancipatory potential of the aesthetic, he locates a more overtly political interpretation of that potential in Schiller's later On the Aesthetic Education of Man. Writing in the shadow of the Terror, Schiller adopts Kant's conception of the aesthetic as a mediating term between the different human faculties, between unmediated desire or sensation, on the one hand, and disembodied reason, understanding, or moral obligation, on the other. He argues that if the French Revolution has taken a wrong turn, this is because the revolutionaries have continued to submit the faculties of desire, sense, and feeling to the hegemony of reason. The aesthetic, understood in Kantian terms as a mediating force between desire and reason, thus offers the promise of a more harmonious 'free play' between these faculties, in which the hierarchy according to which reason dominates feeling would be suspended and genuine freedom achieved. Rancière identifies Schiller's analysis of a statue of a Greek goddess, the Juno Ludovisi, as this aesthetic's 'scène primitive'. ${ }^{9}$ 
For Schiller, the beauty of the Juno Ludovisi reflects the 'idleness and indifferency' of the goddess's countenance, the fact that her expression is free of 'all the earnestness and effort which furrow the cheeks of mere mortals, no less than the empty pleasures which preserve the smoothness of a vacuous face'. Idle, because freed from 'the bonds inseparable from every purpose, every duty, every care', the goddess's countenance embodies that 'happy medium between the realm of law and the sphere of physical exigency' that defines the aesthetic. The aesthetic corresponds to that 'free play' between the faculties that Schiller also terms the 'play drive', that state in which, thanks to the suspension of the hierarchy of reason over sense, any human becomes 'fully a human being', truly free. Through its combination of idleness and self-containment, the Juno Ludovisi thus inspires in viewers a mixture of 'utter repose and supreme agitation', hence moving them to create in reality 'the freest, most sublime state of being' that the statue figures aesthetically. ${ }^{10}$ To quote Rancière:

Pourquoi la statue de la déesse nous attire-t-elle et nous repousse-t-elle en même temps? Parce qu'elle manifeste ce caractère de la divinité qui est aussi, dit Schiller, celui de la pleine humanité: elle ne travaille pas, elle joue. Elle ne cède ni ne résiste. Elle est libre des liens du commandement comme de I'obéissance. Or, cet état d'harmonie s'oppose clairement à celui qui gouverne les sociétés humaines et qui met chacun à sa place en séparant ceux qui commandent et ceux qui obéissent, les hommes du loisir et ceux du travail, les hommes de la culture raffinée et ceux de la simple nature. Le sens commun dissensuel de l'expérience esthétique s'oppose alors aussi bien au consensus de l'ordre traditionnel qu'à celui que la Révolution française a tenté d'imposer. (Malaise, p.132)

Kant and Schiller thus provide Rancière with philosophical accounts of the emancipatory potential of the aesthetic under what he terms 'le regime esthétique de 
I'art'. This 'aesthetic regime', he argues, emerged at the end of the eighteenth century, in the wake of the European democratic revolutions, staging a break with the 'régime' or 'ordre représentatif' that preceded it. The 'representative regime' was based on a hierarchy of genres and subjects that assumed an organic relationship between the social status of fictional characters or represented subjects, the characteristics they embodied, and the actions that expressed that status and those characteristics. The 'aesthetic regime', by contrast, develops 'comme une interminable rupture avec ce modèle hiérarchique du corps, de I'histoire et de I'action. Le peuple libre est, dit Schiller, le peuple qui joue, le peuple incarné dans cette activité qui suspend l'opposition même de I'actif et du passif'. ${ }^{11}$ For Rancière, then, the aesthetic is emancipatory inasmuch as it corresponds to a moment of idleness, a 'rupture' in or 'suspension' of any logic of work or productive activity. This aesthetic of idleness represents a form of 'dissensus' insofar as it exemplifies the capacity of workers, women, immigrants, or slaves to be something other, to occupy another place, to achieve another destiny than that allotted them in the conventional, consensual distribution of places and roles, the existing 'partage du sensible'.

As we have seen, Rancière finds a philosophical account of this 'dissensual' aesthetic experience in the works of Kant and Schiller. He finds empirical, historical evidence of this aesthetic at work in the attempts of nineteenth-century worker-intellectuals to escape their allotted identities and destinies by following paths similar to that proposed by Gabriel Gauny, for whom 'le problème n'est pas de posséder "son" objet mais de se posséder, de développer des forces que rien ne puisse plus satisfaire des présents que I'exploitation offre à la servilité. [...] Le royaume de Baal ne sera renversé que par l'armée des déserteurs qui auront appris à mettre leur coeur là où est leur trésor: ailleurs, nulle part, partout' (Nuit, p.95). Finally, Rancière finds a variety of fictional representations of this relationship between dissensus, idleness, and the aesthetic in a number of the novels, films, and artworks he interprets. 
One striking example is offered by his reading of the fate of Julien Sorel, ostensibly the most active of literary heroes, who nonetheless appears to find greatest happiness in the enforced inactivity of his imprisonment, awaiting his execution at the end of Le Rouge et le noir. Thus, Rancière argues, the socially ambitious plebeian Julien ultimately realises his dream of emancipation not through the means-ends strategizing that drives him throughout the bulk of the novel, but when all such rational calculation is perforce suspended, leaving him in idle contemplation of the sky glimpsed from his prison cell. The novel thus plays off 'deux manières de sortir de la sujétion plébéienne: par le renversement des positions ou par la suspension du jeu même de ces positions' (Aisthesis, p.67). These two paths to emancipation are reflected in the structure of the novel's narrative itself, Rancière maintains. On the one hand, there is the account of Julien's attempts to secure social advancement, an account that depends on a purely rational cause and effect relationship between his character, his motivations, the strategies he therefore follows, and the effects such strategies have, given the objective social structures he must negotiate. On the other hand, the 'pure succession d'actes' which propel Julien to his fate - the letter of denunciation, the shot fired at Madame de Rénal, Julien's passivity on being arrested, his final moments of true happiness in prison - seem to break with any clear logic of cause and effect. To quote Rancière: 'Ainsi l'acte auquel aboutit tout le réseau des intrigues est aussi ce qui I'annule en ruinant toute stratégie des fins et des moyens, toute logique fictionnelle des causes et des effets' (Aisthesis, p.65).

The happiness Julien feels in his prison derives precisely from the suspension of that logic of cause and effect and can be summed up in a simple formula: 'jouir de cette qualité de l'expérience sensible que I'on atteint dès qu'on cesse de calculer, de vouloir et d'attendre, dès qu'on se résout à ne rien faire' (Aisthesis, p.67). Julien's calculated efforts at social advancement clearly reflect one of the effects of the French Revolution, namely the breakdown of the rigid hierarchies of the ancien régime and the opportunities for social mobility this unleashed. The source of Julien's ultimate happiness is to be 
found in what Rancière terms 'l'autre aspect de la revolution égalitaire: la promotion de cette qualité de l'expérience sensible où I'on ne fait rien, qualité également offerte à ceux que l'ordre ancien séparait en hommes de jouissance et hommes de travail' (Aisthesis, p.69). In the happiness Julien derives from his enforced inactivity, then, he experiences both the equality and the freedom whose promise Kant and Schiller had located in their respective aesthetic theories.

Rancière thus locates a tension at the core of Le Rouge et le noir and, by extension, at the heart of the nineteenth-century novel as a whole. As he argues, the historical coincidence of the realist novel and the emergence of the social sciences reflects a shared positivist faith in the possibility of providing a secular account of man's place in the world through an objective description of social structures and institutions and their causal effects on a range of character types' psychologies and trajectories. Cutting across this logic of rational causality are moments such as Julien's happiness in his enforced inactivity, which serve to 'substituer à l'avenir promis par la science sociale et I'action collective le pur non-sens de la vie, celui de la volonté obstinée qui ne veut rien' (Aisthesis, p.75). Hence, according to Rancière, 'le grand genre romanesque vient au jour mordu par son contraire, le bonheur de ne rien faire', the moment of suspense in which is felt 'le seul sentiment de l'existence [...] sans souci des calculs de I'avenir' (Aisthesis, p.76). The tension Rancière locates here in the nineteenth-century novel represents, in microcosm, one manifestation of a more fundamental 'tension', 'contradiction', or 'paradox' intrinsic to the 'aesthetic regime of art'. It is this 'paradoxe fondateur' (Malaise, p.51) that explains how Rancière can find in aesthetics a logic of 'suspense', 'idleness', and 'dissensus', where a thinker like Moulier Boutang will find the opposite there, the promise of a consensual community of feeling, based on a reappropriation of productive labour. 
Rancière traces this founding paradox of aesthetics back to German idealism and the manner in which it theorised the relationship between classical beauty and the values of ancient Greek community this was taken to express. As we have noted, for Rancière the 'idleness and indifferency' Schiller attributes to the countenance of the Juno Ludovisi offers the promise of freedom and equality inasmuch as it figures 'une forme sensible hétérogène par rapport aux formes ordinaires de l'expérience sensible'. Contemplation of the statute's idleness engenders a sensible experience in the viewer that is heterogeneous because it suspends the conventional submission of the faculty of sense to the categories of rational understanding. In this it unleashes a 'free play' of the faculties that itself prefigures a form of political emancipation and equality in which the standard oppositions between a ruling elite, composed of men of action and reason, dominating a popular mass capable only of unreflexive sensation are themselves suspended. As Rancière explains: 'La statue, comme la divinité, se tient en face du sujet, oisive, c'est-à-dire étrangère à tout vouloir, à toute combinaison des moyens et des fins'. This 'free appearance' and the 'free play' of the faculties it engenders in the viewer thus hold out 'la promesse d'une humanité à venir, enfin accordée à la plénitude de son essence' as a community of free and equal beings (Malaise, p.51). However, in a second move, the statue's 'free appearance' is read as the expression of the freedom of the community that created it, a freedom contingent on the fact that ancient Greece supposedly knew no separation between art and everyday life, the statue being the direct translation into stone of 'la croyance commune d'une communauté, identique à sa manière d'être même' (p.52).

At the heart of the project of 'aesthetic education', central to German idealism, is, then, the attempt to make the forms of everyday life coincide with the forms of art, mimicking the model provided by ancient Greece. Yet, according to Rancière, this involves 'une double suppression' of the political stakes of the aesthetic, of the 'heterogeneous sensible's' capacity to figure a suspension of conventional hierarchies in a moment of 'dissensus'. Firstly, the programme of 'aesthetic education', 'fait évanouir 
"I'esthétique" de la politique, la pratique de la dissensualité politique', proposing in its place 'la formation d'une communauté "consensuelle" [...], une comunauté réalisée comme communauté du sentir'. Secondly, in order to achieve this, 'il faut aussi transformer le "libre jeu" en son contraire, en l'activité d'un esprit conquérant qui supprime l'autonomie de l'apparence esthétique, en transformant toute apparence sensible en manifestation de sa propre autonomie' (Malaise, p.54). German idealism's programme of aesthetic education thus corresponds to what Rancière terms a 'metapolitics' that seeks to effect in reality and in the sensible order a task that ordinary politics can only achieve formally, at the level of appearance, as the descent of the French Revolution into the Terror seemed to prove.

These 'metapolitical' assumptions would subsequently be taken up and adapted in Marxism, as evidenced in the conviction that since democratic politics was a mere shadow play driven by the hidden forces of the economic infrastructure, genuine revolution would require that infrastructure be revolutionised, so as to 'donner à I'homme ce dont il n'avait jamais eu que I'apparence' (Malaise, p.55). The problem with such metapolitical assumptions, at the level of politics itself, is that they rest on an opposition between an intellectual elite, which grasps the objective truth of society's laws of functioning, and a mass of people defined by their ignorance or 'misrecognition' of those objective laws. In so doing, metapolitics institutionalises the precise hierarchical opposition whose suspension is figured in the 'free play' of the faculties inherent to the aesthetic. At the level of the arts, meanwhile, such metapolitical assumptions lead to artists and critics attributing 'une fonction éthique' to the artworks they produce or interpret (Aisthesis, p.178).

Rancière argues that this 'ethical' conception of the role of art can be found at work in movements as apparently diverse as the Arts and Crafts Movement, the Futurists, the Werkbund, Bauhaus, and the Soviet Constructivists. Despite their differing political positions and stylistic preferences, what all these movements share, he maintains, is an effort to remodel the forms of life according to the forms of art, they all seek 'la 
reconfiguration d'un monde sensible commun à partir d'un travail sur ses éléments de base, sur la forme des objets de la vie quotidienne' ${ }^{12}$ For all these diverse artistic movements, then, the role of the artist was analogous to that of the architect, the engineer, or the sociologist as an 'observateur engagé qui analyse les formes de vie individualisée produite par les nouvelles structures économiques et les formes de vie collective à promouvoir pour remettre les formes de l'individualité en harmonie avec les exigences d'une communauté' (Aisthesis, p.179). It is, of course, precisely this role that Moulier Boutang adopts in his analyses of Post-Fordist labour. He seeks to describe the 'nouvelles structures économiques' that are shaping the alienated forms of life of contemporary workers and citizens. He then imagines a particular kind of aesthetic experience that might 'remettre les formes de l'individualité en harmonie avec les exigences d'une communauté'. In so doing, Moulier Boutang betrays his reliance on what Rancière would term an 'ethical' conception of the aesthetic. This is a conception based on what, in a reference to the Soviet artistic avant-garde of the 1920s, Rancière describes as 'la suppression conjointe de la dissensualité politique et de I'hétérogénéité esthétique dans la construction des formes de vie et des édifices de la vie nouvelle' (Malaise, p.55).

Against this ethical suppression of the heterogeneous sensible, then, Rancière seeks to defend the aesthetic's capacity to figure moments of suspension of, rupture or dissensus within the conventional hierarchies of experience, dependent precisely on the unmotivated, idle nature of aesthetic experience. The term 'ethical', for Rancière, is always negatively connoted, as is the possibility that artists might play an analogous role to sociologists. He has defined the ethical as 'la pensée qui établit l'identité entre un environnement, une manière d'être et un principe d'action' (Malaise, p.146). As we have noted at some length, for Rancière emancipatory politics always takes the form of a suspension of any such presumed 'identity' between a social environment, a way of being, and a capacity for a particular kind of action. For example, the workerintellectuals he studies in La Nuit des prolétaires all challenge any simple 'identity' 
between the environment they inhabit as workers and their presumed inability to engage in artistic creation or philosophical speculation. The ethical thus plays an analogous function for Rancière to that he attributes to sociology, a discipline that emerged in the wake of the democratic revolutions and sought to 'remake a body for society [...], to reconstitute the social fabric such that individuals and groups at a given place would have the ethos, the ways of feeling and thinking, which corresponded at once to their place and to a collective harmony ${ }^{\prime}{ }^{13}$ To both the ethical conception of the aesthetic and to a sociology that assigns individuals and groups to specific social categories, assuming a simple causal link between those categories and their inherent capacities for thought and action, Rancière opposes a conception of emancipatory politics as a politics of rupture or dissensus. He focuses on those moments when any such fixed identities are suspended in a claim to an equality and a freedom regardless of ascribed status, class, or condition, as exemplified by proletarians who engage in philosophical speculation despite their long working day, women who claim equality despite their supposed biological or maternal function, immigrants who claim full citizenship despite their apparent ethnic difference. Agents and groups thus become political subjects through a 'processus de subjectivation' that is also 'un processus de désidentification et de déclassification' ${ }^{14}$ In the aesthetic, that experience of idle contemplation in which the human faculties are given 'free play', he finds these moments of 'disidentification', of dissensual, interruptive, egalitarian politics prefigured.

This is not to say that Rancière simply ignores the tendency of the aesthetic towards its ethical function, its drive to reconfigure a dissensual democratic community into a harmonious, consensual community of feeling. Rather he seeks to negotiate this 'paradoxe fondateur' of the aesthetic regime of arts, by highlighting those moments of rupture or dissensus that work against the integrative, consensual logic of any possible community of aesthetic feeling. We have already encountered one example of this negotiation in his attempts to play off the emancipatory promise of Julien's contented inactivity at the end of Le Rouge et le noir against the novel's realist depiction of post- 
revolutionary French social structures and the strategies and rational calculations these inspire in its ambitious hero. Another example can be found in Rancière's commentary on Charlie Chaplin's film, Modern Times (1936).

\section{Chaplin Tilting at Windmills}

As Rancière notes, the Constructivist Alexander Rodchenko promoted Chaplin to the status of 'héros du nouveau monde mécanique, entre Lénine et Edison', on the basis of his apparent ability to incarnate a harmonious aesthetic reconciliation between the forms of Fordist assembly-line labour and the forms of modern life (Aisthesis, p.241). Yet, Rancière argues, this is a one-sided interpretation of a character whom commentators like Rodchencko frequently also criticised for giving in to moments of sentimentality that seemed anachronistic in view of the role of 'automate' or 'biomécanicien' they wanted him to incarnate. These moments of sentimental anachronism are precisely what interest Rancière; they represent moments when Chaplin refuses to be integrated into any new community of feeling congruent with the new machine age. For Rancière, even Chaplin's apparent adaptation to the rhythms of assembly-line labour corresponds to a kind of suspension of the will, to a series of mindless repetitive gestures whose effects undo any simple logic of cause and effect, means and pre-programmed end. Chaplin is thus a 'virtuose de la maladresse qui rate tout ce qu'il réussit et réussit tout ce qu'il rate'; he is 'un habitant exemplaire d'un nouvel univers sensible, celui de l'âge des machines qui accomplissent et nient en même temps la volonté et les fins car elles ne se prêtent à ses entreprises qu'en lui imposant en retour la répétition entêtée d'un mouvement dont la perfection propre est de ne rien vouloir lui-même'. In this Chaplin brings to the screen the very 'vertu paradoxale' that Schiller located in the expression of 'idleness and indifferency' on the face of the Juno Ludovisi, 'la vertu de ne rien faire' (Aisthesis, p.241). The art of Chaplin is thus to be found at those moments not when 'la mécanique obéit' but rather 'là où elle se détraque, où se brouille le rapport du commandement à l'exécution, du vivant au mécanique et de l'actif au passif' (Aisthesis, p.240). 
Thus, Rancière concludes, 'les artistes constructeurs de l'avenir' attempt in vain to see 'dans la gestique du petit homme le symbole d'un art synchrone avec la grande épopée de la machine, du travail taylorisé et de l'homme aux gestes exacts'. What Chaplin's 'gestique' actually communicates is 'l'exacte identité de la précision machinique et de la lutte contre les moulins' (Aisthesis, p.242). Chaplin, then, is far from representing the embodiment of that dream of a harmonious relationship between the new forms of machine-age economic life and the forms of art, the dream central to the Soviet avantgarde's ethical conception of the aesthetic. He is, like Don Quixote, an anachronism, whose crumpled suit, bowler hat, and clumsy gait, whose moments of sentimentality and unthinking repetitive gestures put a spanner in the works of the 'grande épopée de la machine', suspending its hierarchies of command and execution, activity and passivity, reason and sense. In so doing, he also upsets the hierarchy between the enlightened Soviet artist-engineer and the unthinking masses that underpins Constructivism. This hierarchy is, according to Rancière, merely an updated version of the founding hierarchy of any metapolitics, of the opposition established in the Republic's parable of the cave between the Platonic philosopher-king who knows the truth and the masses who, mistaking the shadows on the cave wall for reality, languish in a state of ignorance. Chaplin, then, manages to 'renvoyer la puissance démiurgique des machines au jeu des ombres sur les murs de la caverne, au prix peut-être que ces ombres se révèlent plus exactes et plus lucides que les plans des ingénieurs de l'avenir' (Aisthesis, p.243).

In drawing this improbable analogy between Chaplin and Don Quixote, Rancière highlights the importance he attaches to the possibility of anachronism. For him, anachronism is what any history of mentalities must reject or repress in order to maintain its founding assumption that there is a simple identity, a direct causal relationship between a historical period, an objectively definable set of material circumstances, and the thoughts and actions available to those who inhabit that period and those circumstances. Anachronism must also be rejected by any historicist Marxism, which will assume that agents' capacity to think and act is causally related to the stage 
of economic development of the society they inhabit. For Rancière, on the other hand, to repress the possibility of anachronism is to refuse to think the conditions of possibility of any historical 'event' per se. Events happen, he maintains, when someone speaks out of place or acts in anachronistic or untimely fashion.

The historical and social sciences, however, seek to establish an identity between a definable set of material conditions and the actions, thoughts, or words these conditions are presumed to enable given agents to produce. As such, these disciplines are based on 'I'élaboration d'une pensée non-événementielle du temps, d'un temps libéré de I'anachronisme de la parole et de l'événement'. ${ }^{15}$ To refuse to think the possibility of the event is, for Rancière, to refuse to think the possibility of emancipation since the latter must be thought 'à partir de son intempestivité, qui signifie deux choses: premièrement l'absence de nécessité historique qui fonde son existence; deuxièmement son hétérogénéité au regard des formes d'expérience structurées par le temps de la domination' (Moments, p.231). As this article has attempted to show, it is in the idleness of an aesthetic gaze, freed from historical necessity and heterogeneous to the conventional hierarchies according to which reason dominates sense, that Rancière finds the possibility of any such emancipation prefigured. In this sense, his approach defines itself by its opposition to the kind of ethical conception of the relationship between aesthetics and politics, which locates the possibility of emancipation in the aesthetic's promise of a harmonious relationship between the new forms of economic life and new forms of collective life, modelled on the forms of art.

Rancière thus allows us to identify in Moulier Boutang's work the presence of merely the latest iteration of the ethical conception of art, with its associated project of aesthetic education. Where the Constructivists sought aesthetic and political revolution in the reconciliation of the forms of everyday life with the economic structures of Fordism, Moulier Boutang seeks an equivalent revolution and reconciliation, updated to reflect the economic structures of Post-Fordism. As we have seen, Rancière opposes to this ethical conception of the aesthetic, an emphasis on the aesthetic as a fleeting moment of 
idleness, in which conventional conceptual and political hierarchies are disrupted or suspended. The fleeting nature of this conception of political emancipation is the source of the most frequent criticism levelled at his work, namely that such moments constitute fragile grounds for any lasting collective political movements and that his work hence pays insufficient attention to the material conditions that respectively constrain or enable those more durable forms of political agency. It is, of course, this kind of assumption of a causal relationship between material conditions and political agency that underpins the work of neo-operaists like Moulier Boutang and the updated projects of 'aesthetic education' they implicitly endorse. The onus is therefore surely on Rancière's critics to demonstrate how their calls for a greater attentiveness to these supposedly causal relationships between material conditions and political agency do not simply reenact the 'suppression of dissensus' that Rancière argues is inherent to any such metapolitical project. It is surely significant in this light that, in his most recent work, Maurizio Lazzarato, formerly one of Moulier Boutang's close collaborators, seems to have moved much closer to Rancière's position on this issue. As we noted earlier in this article, Lazzarato's break with theories of 'cognitive capitalism' has obliged him to seek alternative paths to emancipation than that supposedly offered by the promise of a collective re-appropriation of the cognitive and affective capacities now integrated into the productive process. This, in turn, has led him to return to the refusal of work as a primary political tactic, yet this is a notion of refusal that bears the traces of a significant engagement with Rancière's thought.

Thus Lazzarato now understands the refusal of work to correspond to the kind of 'suspension' of or 'disidentification' from fixed or assigned social identities that Rancière argues is both central to the politics of emancipation and prefigured in the aesthetic experience. The strike proved an effective form of the refusal of work, Lazzarato argues, 'parce qu'elle bloquait la valorisation du capital, mais aussi parce qu'elle rendait les ouvriers "égaux" en les faisant sortir d'une division du travail dans laquelle ils étaient assignés à des fonctions et des places différentes et concurrentes' (Dette, p.201). He 
combines this re-reading of the operaist refusal of work not only with Rancière's aesthetics of idleness, but also with Paul Lafargue's Droit à la paresse, to assert that 'I'action "paresseuse" est un opérateur de désidentification' (Dette, p.205). It is this capacity for 'disidentification', rather than any identity conferred by one's position in the relations of production, that enables political agency: 'ce n'est pas le cognitif ou l'immatériel ou toute autre définition tirée de la production qui qualifie l'action politique, mais le refus et la capacité de fuir les catégories, les identités, les rôles de la division sociale du travail et d'ouvrir des possibles. Le refus et son potentiel d'action politique ne sont pas directement déductibles du "travail", de la place et des fonctions auxquelles nous sommes assignées' (Dette, p.207). Thus, Lazzarato concludes, 'I'action paresseuse ne requiert aucune virtuosité, aucun savoir-faire spécialisé, cognitif ou professionnel. Elle peut être exercée par tout le monde' (Dette, p.207).

Lazzarato has come quite a long way here in challenging and reformulating one of the founding assumptions of operaism. For in Tronti's original formulation, the power of refusal was read as a direct expression of the workers' position in the relations of production, of their status as an inherently antagonistic force integrated within 'the system of capitalism [...] independent of it and opposed to it' (Operai, p.34, my translation). This reformulation of operaism's founding assumptions owes a considerable debt to Rancière. For, as we have seen, it is precisely this capacity to suspend one's assignation to or identification with any fixed role or status, a capacity that is, at least virtually, open to anyone at all, that Rancière finds prefigured in the idleness of aesthetic contemplation. Lazzarato's most recent work therefore suggests that he has joined Rancière in wagering that any political emancipation must be thought as an emancipation from work rather than an emancipation through work. 


\section{NOTES}

1. Yann Moulier Boutang, Le Capitalisme cognitif: la nouvelle grande transformation, (Paris: Editions Amsterdam, 2007), p.109. Subsequent references will be to ' $C C^{\prime}$, in parentheses in the text.

2. Paolo Virno, A Grammar of the Multitude. For an analysis of contemporary forms of life, trans. I. Bertoletti, J. Cascaito, A. Casson, (New York: Semiotext(e), 2004), p.55. Subsequent references will be to 'GoM', in parentheses in the text.

3. Mario Tronti, Operai e capitale, (Turin: Einaudi, 1966). Subsequent references will be to 'Operai', in parentheses in the text.

4. Gilles Deleuze, Pourparlers, 1972-1990, (Paris: Minuit, 2003), pp.229-47.

5. Jacques Rancière, Moments politiques. Interventions 1977-2009, (Paris: La Fabrique, 2009), pp.162-63. Subsequent references will be to 'Moments', in parentheses in the text.

6. Jodi Dean, 'Politics without Politics', in Paul Bowman \& Richard Stamp, eds. Reading Rancière, (London: Continuum, 2011), pp.73-94.

7. Maurizio Lazzarato, Gouverner par la dette, (Paris: Les Prairies ordinaires, 2014), p.204. Subsequent references will be to 'Dette', in parentheses in the text.

8. Jacques Rancière, La Nuit des prolétaires. Archives du rêve ouvrier, (Paris: Fayard/Hachette Littératures, 1981), p.70. Subsequent references will be to 'Nuit', in parentheses in the text.

9. Jacques Rancière, Malaise dans l'esthétique, (Paris: Editions Galilée, 2004), p.134. Subsequent references will be to 'Malaise', in parentheses in the text.

10. Friedrich Schiller, On the Aesthetic Education of Man in a Series of Letters, trans. E.M.Wilkinson \& L.A.Willoughby, (Oxford: Oxford University Press 1967), pp.105-09. 
11. Jacques Rancière, Aisthesis. Scènes du regime esthétique de l'art, Paris: Editions Galilée, 2011, p.15. Subsequent references will be to 'Aisthesis', in parentheses in the text.

12. Jacques Rancière, Le Destin des images, (Paris: La Fabrique, 2003), p.115.

13. Jacques Rancière, 'Thinking Between the Disciplines: an aesthetics of knowledge', trans. J.Roffe, Parrhesia, no.1, 2006, pp.1-12 (p.7).

14. Jacques Rancière, Aux bords du politique, (Paris: Gallimard/Folio-Essais, 1998), p.119.

15. Jacques Rancière, Les Mots de I'histoire. Essai poétique du savoir, (Paris: Seuil/Points, 1992), p.55. 